\title{
Evaluation of the Effects of Organic Matter and Other Soil Characteristics Upon the Aggregate Stability of Some Tropical Soils ${ }^{1}$
}

\author{
M. A. Lugo-López and J. Juárez, Jr. ${ }^{2}$
}

\section{INTRODUCTION}

The degree of stability of soil aggregates is one of the most important soil characteristics because of its bearing on utilization and conservation. It is particularly important in irrigated soils where highly stable aggregates, other conditions being favorable, allow water to penetrate quickly into the soil; unstable aggregates disperse upon immersion, clog the soil voids, and consequently drainage problems are likely to develop.

The degree of stability is influenced by the presence of binding substances produced through the activity of soil organic matter, and by the physical attractions of clay and fine silt particles themselves. In other areas of the world some relationships have been worked out to determine the degree of influence of organic matter and clay upon aggregate stability. However, no such relationships have been worked out for soils of tropical regions.

This paper reports on studies conducted with soils from the newly developed irrigated area in the Lajas Valley in southwestern Puerto Rico in an attempt to evaluate the stability of soil aggregates in terms of the organic-matter, clay, or silt content of the soils.

\section{SOILS AND METHODS}

\section{SOILS STUDIED}

In this study 23 soil profiles from the Lajas Valley irrigation development project were included. They comprised the major soils of the area. The soils studied include soils of the Aguirre, Guánica, Santa Isabel, Fraternidad, $\mathrm{Fe}$, and Jácana series $(3)^{3}$. These soils are generally very deep with a strikingly high, almost uniform clay content of the expandinglattice type, predominantly small pores, very slow hydraulic conductivity in the subsoil, very low aggregate stability below the surface layer, but with a topsoil of about 1 foot, in some cases almost 2 feet, that conducts

1 Joint contribution from the Gurabo Substation and the Department of Soils.

2 Soil Scientist in Charge of the Gurabo Substation, and Research Assistant in Soils, respectively, Agricultural Experiment Station, University of Puerto Rico, Rio Piedras and Gurabo, P.R. Appreciation is expressed to E. J. Brenes and R. Pérez-Escolar, both Assistant Soil Scientists at the Station, for their critical review of the manuseript.

3 Italic numbers in parentheses refer to Literature Cited, p. 272. 
water rather well. They are relatively low in organic matter and nitrogen, and generally high in soluble salts and exchangeable sodium, which increases with depth.

\section{SAMPLING}

The sampling was done as a part of a more extensive study on the nature and properties of the major soils of the Lajas Valley ( $(s)$. Pits 4 feet wide, 4 feet long, and 6 feet deep were dug at 23 selected, scattered, and distant places concentrated mainly at the eastern and central sections of the Valley. Bulk samples were taken from each visually differentiated horizon.

\section{ANALYTICAL METHODS}

Aggregate stability was determined by the method of Bryant, Bendixen, and Slater (1) and organic matter by the chromic acid-reduction method.

TABLE 1.-Summary of the statistical analyses to determine the influence of organic matter, clay, and silt upon soil aggregates slability

\begin{tabular}{l|c|c}
\hline Independent variable & $\begin{array}{c}\text { Number of pairs } \\
\text { of observations }\end{array}$ & Correlation coefficient \\
\hline Organic matter & 129 & $0.395^{1}$ \\
Clay & 127 & .030 \\
Silt & 127 & .022 \\
\hline
\end{tabular}

1 Highly significant.

Particle-size distribution was made by the standard pipette method. Simple regression studies were conducted where aggregate stability was considered the dependent variable and organic matter, clay content, or silt content were the independent variables. Coefficients of correlation and determination were calculated in each case.

\section{RESULTS AND DISCUSSION}

Table 1 summarizes the results of the statistical studies conducted to determine the respective influence of organic-matter, clay, and silt contents upon soil-aggregate stability. No significant correlation was obtained when clay content or silt content was considered as the independent variable. A highly significant correlation was obtained between aggregate stability and organic-matter content where a total of 129 pairs of observations were considered. However, only 16 percent of the variability on the measured aggregate stability could be explained on a basis of the organic-matter content of the soils.

Estimates of the percentage of water-stable aggregates can be made 
by using a linear regression as a first approximation by means of the equation:

$$
Y=a+b X
$$

TABLE 2.-Comparison of measured aggregate-stability values and values calculated on a basis of the organic-matter content of soils, in percentage

\begin{tabular}{c|c|c|c}
\hline $\begin{array}{c}\text { Organic-matter } \\
\text { content }\end{array}$ & $\begin{array}{c}\text { Measured-aggregate } \\
\text { stability }\end{array}$ & $\begin{array}{c}\text { Calculated-aggregate } \\
\text { stability }\end{array}$ & Deviation \\
\cline { 2 - 3 } 10.9 & 43.5 & 48.4 & 4.9 \\
2.8 & 17.7 & 17.8 & .1 \\
1.9 & 19.4 & 14.5 & -4.9 \\
1.4 & 11.2 & 12.6 & 1.4 \\
.6 & 9.6 & 9.6 & 0 \\
5.0 & 25.7 & 26.2 & .5 \\
3.9 & 24.0 & 22.0 & -2.0 \\
.2 & 6.7 & 8.1 & 1.4 \\
1.4 & 15.5 & 12.6 & -2.9 \\
.3 & 8.1 & 8.5 & .4 \\
1.7 & 18.9 & 13.8 & -5.1 \\
1.0 & 13.8 & 11.1 & -2.7 \\
2.8 & 17.6 & 17.9 & .3 \\
1.1 & 11.7 & 11.5 & -.2 \\
.8 & 6.0 & 10.3 & 4.3 \\
2.3 & 12.2 & 16.0 & 3.8 \\
.9 & 9.3 & 10.7 & 1.4 \\
.6 & 7.0 & 9.6 & 2.6 \\
.8 & 9.3 & 10.3 & 1.0 \\
.5 & 7.0 & 9.2 & 2.2 \\
.4 & 12.0 & 8.8 & -3.2 \\
1.2 & 12.4 & 11.6 & -.8 \\
3.1 & 22.2 & 19.0 & -3.2 \\
2.2 & 9.2 & 8.3 & -.9 \\
\hline & & & -8 \\
\hline
\end{tabular}

${ }^{1}$ Calculated from the equation: $Y=7.33+3,77 X$, where $Y$ is the estimated aggregate stability and $X$ is the measured organic-matter content of the soils.

where

$Y=$ percentage aggregate stability to be estimated,

$a=$ constant calculated on basis of the mean aggregate stability, mean organic-matter content, and the regression coefficient,

$b=$ regression coefficient, and

$X=$ mean organic-matter content.

Table 2 shows a comparison of some of the measured aggregate-stability values and those estimated on basis of the organic-matter content of the 
soils. The deviations of the estimated from the measured values range between -5.1- to 4.9-percent water-stable aggregates.

It must be kept in mind, however, that the usefulness of the equation developed is seriously limited because of the rather low percentage of the variability in aggregate stability that can be explained on basis of organicmatter content.

Pérez-Escolar (4) in his studies to determine the nature of aggregation in latosols found that the destruction of organic matter with hydrogen peroxide caused considerable dispersion of the soil aggregates. Table 3, adapted from Pérez-Escolar (4), shows that the clay percentage measured by the pipette method was almost twice as large in treated soils as in soils not treated with hydrogen peroxide. The high stability of aggregates in latosols have been attributed (2) to the interrelationship between soil organic matter and iron oxides.

TABLE 3.-Percenlage of clay particles in aggregales of three sizes (millimeters) as affected by hydrogen peroxide trealment ${ }^{1}$

\begin{tabular}{c|c|c}
\hline \multirow{2}{*}{ Aggregate size } & \multicolumn{2}{|c}{ Percentage of clay in indicated treatment } \\
\cline { 2 - 3 } & Untreated soil & Soil treated with $\mathrm{H}_{2} \mathrm{O}$ \\
\hline $5-3$ & 33.8 & 60.0 \\
$3-2$ & 32.3 & 61.7 \\
$2-1$ & 33.7 & 61.0 \\
\hline
\end{tabular}

1 Adapted from Pérez-Escolar (4).

Thus, it can be stated that organic matter is probably the most important single agent determining aggregate stability in soils. Although the percentage of variability in aggregate stability that can be explained on the basis of organic-matter content is not high, it is the only single factor among those studied which could account for any variability at all, the correlation being highly significant.

\section{SUMMARY}

This paper reports on statistical studies conducted to evaluate the degree of stability of soil aggregates in terms of the respective organic-matter, clay, and silt contents of selected soils from the Lajas Valley irrigation development project. Simple regression analyses revealed that there was no correlation between aggregate stability and clay or silt content. However, a highly significant correlation was obtained when organic-matter content was considered as the independent variable. In spite of the level of significance only 16 percent of the variability in aggregate stability can 
be explained on a basis of the soil organic-matter content, thus limiting the possible usefulness of estimates made by using the equation developed.

\section{RESUMEN}

Se informan aquí los resultados de estudios estadísticos realizados con la intención de evaluar el grado de estabilidad de los agregados o unidades estructurales de un número seleccionado de suelos del Valle de Lajas en términos de los contenidos de materia orgánica, arcilla o limo. Los análisis de regresión sencilla revelaron que no hay correlación entre la estabilidad de los agregados y el contenido de arcilla o limo. Sin embargo, cuando el contenido de materia orgánica se consideró como la variable independiente se encontró una correlación altamente significativa. A pesar del alto nivel de correlación, solamente es posible explicar un 16 por ciento de la variación en estabilidad de los agregados a base del contenido de materia orgánica. Esto limita considerablemente la utilidad posible de hacer estimados por medio de la ecuación matemática desarrollada.

\section{LITERATURE CITED}

1. Bryant, J. C., Bendixen, T. W., and Slater, C. W., Measurement of water stability of soils, Soil Sci. 65 341-5, 1948.

2. Lugo-Lbpez, M. A., and Pérez-Escolar, R., La materia orgánica en los suelos de la zona cafetalera de Puerto Rico, Rev. de Agr. de P. R. 64 (2) 85-92, 1957.

3. Lugo-López, M. A., Pérez-Escolar, R., Acevedo, G., and Juárez Jr., P., Nature and Properties of Major Soils of the Lajas Valley, Univ. P. R. Agr. Exp. Sta. Bul. 149, 1959.

4. Pérez-Escolar, R., Nature of Lateritic Soil Aggregates, Unpublished M. S. thesis, Rutgers University Library, New Brunswick, N. J., 1956. 